\title{
Oospore Formation by Phytophthora infestans in Potato Tubers
}

\author{
Aaron Levin, Alexander Baider, Evgenia Rubin, Ulrich Gisi, and Yigal Cohen
}

First, second, third, and fifth authors: Faculty of Life Sciences, Bar-Ilan University, Ramat-Gan 52900, Israel; and fourth author: Research Biology, Syngenta Crop Protection, Stein, Switzerland. Accepted for publication 2 March 2001.

\begin{abstract}
Levin, A., Baider, A., Rubin, E., Gisi, U., and Cohen, Y. 2001. Oospore formation by Phytophthora infestans in potato tubers. Phytopathology 91:579-585.

The ability of Phytophthora infestans, the causal agent of potato and tomato late blight, to produce oospores in potato tuber tissue was studied in the field and under laboratory conditions. In 1998 and 2000 field experiments, the canopy of potato cvs. Alpha and Mondial, respectively, were coinoculated with A1 + A2 sporangia of the fungus, and the infected tubers collected at harvest were examined for the presence of oospores. In 1998, only 2 of 90 infected tubers had oospores, whereas none of the 90 tubers examined in 2000 had any oospores. In the latter experiment, infected tubers kept in storage up to 12 weeks after harvest had no oospores. Artificial co-inoculations of whole tubers with $\mathrm{A} 1+\mathrm{A} 2$ sporangia resulted only rarely in the formation of oospores
\end{abstract}

ABSTRACT inside the tubers. Co-inoculations of potato tuber discs taken from dormant tubers 0 to 16 weeks after harvest failed to support any oospore production, whereas discs taken from sprouting tubers of $\geq 18$ weeks after harvest allowed oospores to form. Tuber discs showed enhanced oospore formation when treated before inoculation with either sugars, amino acids, casein hydrolysate, $\beta$-sitosterol, or chloroethylphosphonic acid. In contrast, reducing airflow into the petri dishes where potato tuber discs were incubated reduced the number of oospores produced. The number of oospores produced in tuber tissue was lower compared with that in leaf tissue regardless of the origin of isolates used. The data show that the ability of Phytophthora infestans to produce oospores in potato tuber tissue is very limited and increases with tuber aging.

Additional keywords: epidemiology, mating type, sexual reproduction.
Since the displacement of the old population and the appearance of the A2 mating type of Phytophthora infestans (Mont.) de Bary, in the Western Hemisphere approximately 20 years ago $(12,17-$ $19,23,24,29,42)$ oospore formation due to mating with the existing or immigrating A1 mating type has been reported in various countries $(2,3,5,9,10,16,26,28,32,35,38)$. Mating threatens potato and tomato industries worldwide due to the possible emergence of recombinant fungal genotypes with enhanced aggressiveness and wider virulence $(3,11,15,18,20-22,25,37)$. The role of oospores in the epidemiology of late blight is not fully known. Unlike other downy mildews, such as Plasmopara viticola in grapes (1) and Plasmopara halstedii in sunflowers (8) for which oospores bear a critical role in the initiation of the disease in the field, no direct evidence proves a similar role for the oospores of Phytophthora infestans.

Oospores of Phytophthora infestans are produced in small numbers in the canopy of field-grown potato and tomato $(10,40)$. Their formation in leaf tissue requires excessive rain (overhead irrigation) in the field (6) or floating on water in the laboratory (7). Whether they are produced in high-enough numbers in leaf tissue to play a role in the epidemiology of late blight is unknown.

Not only are oospores produced in very small numbers in the field, their germination is quite low. Their germination in the laboratory requires pretreatments with chemicals, enzymes, watersnail digestion (3), or other factors (4).

An important question in the biology of Phytophthora infestans is whether the fungus can produce oospores in potato tubers and inside tomato fruits and seeds. Our previous studies $(6,26)$ showed that infected tubers rarely carry oospores, and the literature provides little evidence on the production of oospores in potato

Corresponding author: Y. Cohen; E-mail address: coheny@mail.biu.ac.il

Publication no. P-2001-0402-02R

(C) 2001 The American Phytopathological Society tubers. In contrast, tomato fruits allow for the formation of abundant oospores in the pericarp and around the seeds (40; Y. Cohen, unpublished data).

Our objective for this research was to study the ability of Phytophthora infestans to produce oospores in potato tubers. Potato tubers are globally traded in large quantities. If present in tubers, oospores may be shipped to remote locations, thereby introducing new recombinant genotypes of the fungus to new areas.

\section{MATERIALS AND METHODS}

Field observations. Two studies were done in the field, one in 1998 and the other in 2000. In the first study, three plots, each $21 \mathrm{~m}^{2}$, of potato cv. Alpha were inoculated December 1998, 6 weeks after planting, with three $\mathrm{A} 1+\mathrm{A} 2$ isolate combinations, one in each plot (Table 1). Forty days after inoculation, when foliage in all three plots was fully blighted, tubers were harvested. Thirty tubers (5- to 6-cm diameter) with symptoms of late blight were randomly selected from each plot, stored in paper bags at $20^{\circ} \mathrm{C}$ for 2 weeks, and examined for the presence of oospores. In the second study, a potato field of $\mathrm{cv}$. Mondial $\left(60 \mathrm{~m}^{2}\right)$ was inoculated November 1999, 6 weeks after planting, with one A1 + A2 sporangial mixture (Table 1). At 43 days, when the canopy was completely destroyed by the fungus, 90 tubers with symptoms were selected, stored in paper bags at $15^{\circ} \mathrm{C}$, and two to three tubers were examined for oospores at weekly intervals for 12 weeks.

Tubers were examined for oospores by cutting them in half; five thin slices $(1 \times 1 \times 0.1 \mathrm{~cm})$ were cut from the necrotic area of each half tuber. The slices were boiled for $30 \mathrm{~min}$ in $1 \% \mathrm{HCl}$, rinsed in water, and mounted on glass slides in $50 \%$ glycerol for microscopical examination.

The cut tuber halves were also placed in plastic jars $(200 \mathrm{ml})$, two halves per jar, and incubated at $15^{\circ} \mathrm{C}$ to allow for sporangial production. In the second year, the sporangia were collected and used for mating type determination (7). 
Whole tuber inoculation. Three experiments were done with whole tubers. In the first experiment, healthy tubers (cv. Mondial) were harvested from the field, stored at $4^{\circ} \mathrm{C}$, and inoculated with Phytophthora infestans 2 months later. Inoculation was done by immersing the tubers in a mixture of A1 (isolate TO497) and A2 (isolate 317 ) sporangia (1:1 ratio, 2,000 sporangia per $\mathrm{ml})$ for $1 \mathrm{~h}$ at $15^{\circ} \mathrm{C}$. Tubers were then kept in a moisture-saturated atmosphere at $15^{\circ} \mathrm{C}$ in the dark and examined for oospores at biweekly intervals. The second experiment was conducted with old sprouting tubers $\left(8\right.$ months after harvest and stored at $4^{\circ} \mathrm{C}$ ) of cvs. Nicola, Clauster, and Mondial. Such tubers seldom get infected if inoculated by immersion (27). Inoculation therefore was conducted by pipetting A1 + A2 sporangia (isolates $314+317$ ) into a $10-\mathrm{mm}$ deep wound stitched along the tuber. Tubers were incubated at $15^{\circ} \mathrm{C}$ and examined $(n=3)$ for oospores at 2 and 4 weeks after inoculation. In the third experiment, we examined oospore formation in potato tubers at different temperatures. Seven-month-old sprouting potato tubers of cv. Alpha were incision-inoculated with either isolates $314+317$ or $\mathrm{BI}+\mathrm{KG}$, incubated for 1 day at $15^{\circ} \mathrm{C}$ to ensure infection, and stored for either $5,11,17$, or $23^{\circ} \mathrm{C}$ under moisture-saturated atmosphere in the dark.

Inoculation of tuber discs. Tubers were sliced into 3-mm-thick slices with the aid of an electric kitchen slicer. Tuber discs were prepared from these tuber slices with a 10-mm-diameter cork borer. Discs were thoroughly washed with water, blotted dry, held for $1 \mathrm{~h}$, and placed in 9-cm petri dishes on dry 7-cm-diameter Whatman No. 1 filter paper, 10 discs per dish (unless stated otherwise). Each disc was inoculated with one $10-\mu$ l droplet of A1 + A2 (1:1 ratio) sporangial suspension $\left(2 \times 10^{3}\right.$ per $\left.\mathrm{ml}\right)$ and incubated at $15^{\circ} \mathrm{C}$ in the dark to allow for oospore formation. Care was taken

TABLE 1. Pairing of A1 + A2 isolates of Phytophthora infestans used for oospore formation

\begin{tabular}{|c|c|c|c|c|c|}
\hline Experiment & Isolate pairing & Source ${ }^{x}$ & Origin $^{y}$ & $\begin{array}{c}\text { Mating } \\
\text { type }\end{array}$ & $\mathrm{MS}^{\mathrm{z}}$ \\
\hline \multicolumn{6}{|l|}{ Field } \\
\hline \multirow[t]{2}{*}{1998} & $\mathrm{GE}+\mathrm{EHF}$ & $\mathrm{P}+\mathrm{P}$ & $\mathrm{I}+\mathrm{I}$ & $\mathrm{A} 1+\mathrm{A} 2$ & $S+R$ \\
\hline & $314+317$ & $P+P$ & $\mathrm{~J}+\mathrm{J}$ & $\mathrm{A} 1+\mathrm{A} 2$ & $S+R$ \\
\hline 2000 & TO497 + 317 & $\mathrm{~T}+\mathrm{P}$ & $\mathrm{C}+\mathrm{J}$ & $\mathrm{A} 1+\mathrm{A} 2$ & $S+R$ \\
\hline \multicolumn{6}{|l|}{ Laboratory } \\
\hline \multirow{3}{*}{ Whole tubers } & TO497 + 317 & $T+P$ & $\mathrm{C}+\mathrm{J}$ & $\mathrm{A} 1+\mathrm{A} 2$ & $S+R$ \\
\hline & $314+317$ & $\mathrm{P}+\mathrm{P}$ & $\mathrm{J}+\mathrm{J}$ & $\mathrm{A} 1+\mathrm{A} 2$ & $S+R$ \\
\hline & $\mathrm{BI}+\mathrm{KG}$ & $\mathrm{T}+\mathrm{T}$ & $\mathrm{I}+\mathrm{I}$ & $\mathrm{A} 1+\mathrm{A} 2$ & $\mathrm{~S}+\mathrm{s}-2-2+$ \\
\hline \multicolumn{6}{|l|}{ Tuber discs } \\
\hline \multirow[t]{17}{*}{ Israel } & TO497 + 317 & $\mathrm{~T}+\mathrm{P}$ & $\mathrm{C}+\mathrm{J}$ & $\mathrm{A} 1+\mathrm{A} 2$ & $S+R$ \\
\hline & TO497 + US-7 & $\mathrm{T}+\mathrm{P}$ & $\mathrm{C}+\mathrm{US}$ & $\mathrm{A} 1+\mathrm{A} 2$ & $S+R$ \\
\hline & TO497 + KG & $T+T$ & $\mathrm{C}+\mathrm{I}$ & $\mathrm{A} 1+\mathrm{A} 2$ & $S+S$ \\
\hline & TO497 + TUR & $\mathrm{T}+\mathrm{T}$ & $\mathrm{C}+\mathrm{T}$ & $\mathrm{A} 1+\mathrm{A} 2$ & $S+S$ \\
\hline & $314+317$ & $\mathrm{P}+\mathrm{P}$ & $\mathrm{J}+\mathrm{J}$ & $\mathrm{A} 1+\mathrm{A} 2$ & $S+R$ \\
\hline & $314+$ US-7 & $\mathrm{P}+\mathrm{P}$ & $\mathrm{J}+\mathrm{US}$ & $\mathrm{A} 1+\mathrm{A} 2$ & $S+R$ \\
\hline & US- 1 + US-8 & $\mathrm{P}+\mathrm{P}$ & $\mathrm{US}+\mathrm{US}$ & $\mathrm{A} 1+\mathrm{A} 2$ & $S+R$ \\
\hline & $870+\mathrm{KG}$ & $\mathrm{T}+\mathrm{T}$ & $\mathrm{I}+\mathrm{I}$ & $\mathrm{A} 1+\mathrm{A} 2$ & $S+S$ \\
\hline & $870+$ TUR & $T+T$ & $I+T$ & $\mathrm{~A} 1+\mathrm{A} 2$ & $S+S$ \\
\hline & $870+317$ & $\mathrm{~T}+\mathrm{P}$ & $\mathrm{I}+\mathrm{J}$ & $\mathrm{A} 1+\mathrm{A} 2$ & $S+R$ \\
\hline & $96933+\mathrm{KG}$ & $P+T$ & $\mathrm{UK}+\mathrm{I}$ & $\mathrm{A} 1+\mathrm{A} 2$ & $S+S$ \\
\hline & $96933+317$ & $\mathrm{P}+\mathrm{P}$ & $\mathrm{UK}+\mathrm{J}$ & $\mathrm{A} 1+\mathrm{A} 2$ & $S+R$ \\
\hline & 96933 + US-7 & $\mathrm{P}+\mathrm{P}$ & $\mathrm{UK}+\mathrm{US}$ & $\mathrm{A} 1+\mathrm{A} 2$ & $S+R$ \\
\hline & $\mathrm{BI}+\mathrm{KG}$ & $T+T$ & $\mathrm{I}+\mathrm{I}$ & $\mathrm{A} 1+\mathrm{A} 2$ & $S+S$ \\
\hline & $\mathrm{GR}+\mathrm{YA}$ & $\mathrm{T}+\mathrm{T}$ & $\mathrm{I}+\mathrm{I}$ & $\mathrm{A} 1+\mathrm{A} 2$ & $S+S$ \\
\hline & BR-5 + YA & $\mathrm{T}+\mathrm{T}$ & $\mathrm{I}+\mathrm{I}$ & $\mathrm{A} 1+\mathrm{A} 2$ & $S+S$ \\
\hline & $\mathrm{HA}+\mathrm{TUR}$ & $\mathrm{T}+\mathrm{T}$ & $\mathrm{I}+\mathrm{T}$ & $\mathrm{A} 1+\mathrm{A} 2$ & $\mathrm{R}+\mathrm{S}$ \\
\hline \multirow[t]{6}{*}{ Switzerland } & TO497 + 317 & $\mathrm{~T}+\mathrm{P}$ & $\mathrm{C}+\mathrm{J}$ & $\mathrm{A} 1+\mathrm{A} 2$ & $S+R$ \\
\hline & TO497 + CH46.97 & $\mathrm{T}+\mathrm{P}$ & $\mathrm{C}+\mathrm{C}$ & $\mathrm{A} 1+\mathrm{A} 2$ & $S+S$ \\
\hline & TO497 + CHT20.97 & $\mathrm{T}+\mathrm{T}$ & $\mathrm{C}+\mathrm{C}$ & $\mathrm{A} 1+\mathrm{A} 2$ & $S+S$ \\
\hline & $\mathrm{CH} 22.98+\mathrm{CHT} 20.97$ & $P+T$ & $\mathrm{C}+\mathrm{C}$ & $\mathrm{A} 1+\mathrm{A} 2$ & $R+S$ \\
\hline & $\mathrm{CH} 22.98+\mathrm{CH} 46.97$ & $P+P$ & $\mathrm{C}+\mathrm{C}$ & $\mathrm{A} 1+\mathrm{A} 2$ & $R+S$ \\
\hline & $\mathrm{CH} 22.98+317$ & $\mathrm{P}+\mathrm{P}$ & $\mathrm{C}+\mathrm{J}$ & $\mathrm{A} 1+\mathrm{A} 2$ & $R+R$ \\
\hline
\end{tabular}

${ }^{\mathrm{P}} \mathrm{P}=$ potato and $\mathrm{T}=$ tomato.

${ }^{\text {y }} \mathrm{C}=$ Switzerland, $\mathrm{I}=$ Israel, $\mathrm{J}=$ Japan, $\mathrm{T}$ = Turkey, UK = United Kingdom, and US $=$ United States.

${ }^{\mathrm{z}}$ Metalaxyl sensitivity: $\mathrm{S}=$ sensitive and $\mathrm{R}=$ resistant. while doing these experiments to avoid bacterial contamination. This was mainly achieved by carefully drying the tuber tissue before inoculation.

External application of chemicals. All chemicals were purchased from (Sigma Chemical, St. Louis). Tuber discs were prepared as previously described and one 50- $\mu$ droplet of a chemical solution was applied onto each disc. Discs were allowed to dry and were inoculated in petri dishes as previously described.

Fungal isolates. Thirteen A1 and nine A2 isolates of Phytophthora infestans were used. They were mixed in 22 A1 + A2 combinations. Sixteen combinations were used in Israel (four of them in the field) and six combinations in Switzerland (Table 1). Isolates were either collected from potato or tomato crops in Israel and Switzerland or received as a gift from external sources (Table 1). Isolates were maintained on rye agar medium at $15^{\circ} \mathrm{C}$ in the dark. Inoculum was increased on tuber slices in petri dishes. Sporangia were collected after 7 to 10 days. Mating type and sensitivity to metalaxyl were conducted as described $(7,30)$.

Oospore counting. To quantitatively determine oospore formation in tuber discs the following procedure was undertaken: discs were placed in $1 \% \mathrm{HCl}$, boiled on a hot plate for $30 \mathrm{~min}$ to dissolve starch grains, washed with water, mounted in $50 \%$ glycerol solution on glass slides, covered with a cover slip, pressed gently, and examined with a dissecting microscope at $\times 40$ and $\times 160$ magnification.

Oospore counts in artificially inoculated whole tubers were done by slicing a tuber into 3-mm-thick slices, cutting out all necrotic areas of the slices into small pieces and mounting the pieces on glass microscope slides after being treated with $\mathrm{HCl}$ as previously described. Oospore formation in leaf tissue was also examined for comparison purposes.

Oospore formation in leaf discs. Leaflets from 6-week-old, greenhouse-grown, potted potato plants (cvs. Alpha and Mondial) were used to prepare 10-mm-diameter discs. These were placed on moist filter paper in 9-cm petri dishes and inoculated with $\mathrm{A} 1+$ A2 (1:1 ratio) sporangial mixture $\left(2 \times 10^{3}\right.$ per ml), one $10-\mu$ droplet per disc. Dishes were incubated at $15^{\circ} \mathrm{C}(12 \mathrm{~h} \mathrm{light/day) \text {for }}$ 10 days, then clarified with boiling ethanol and examined for oospore production (7).

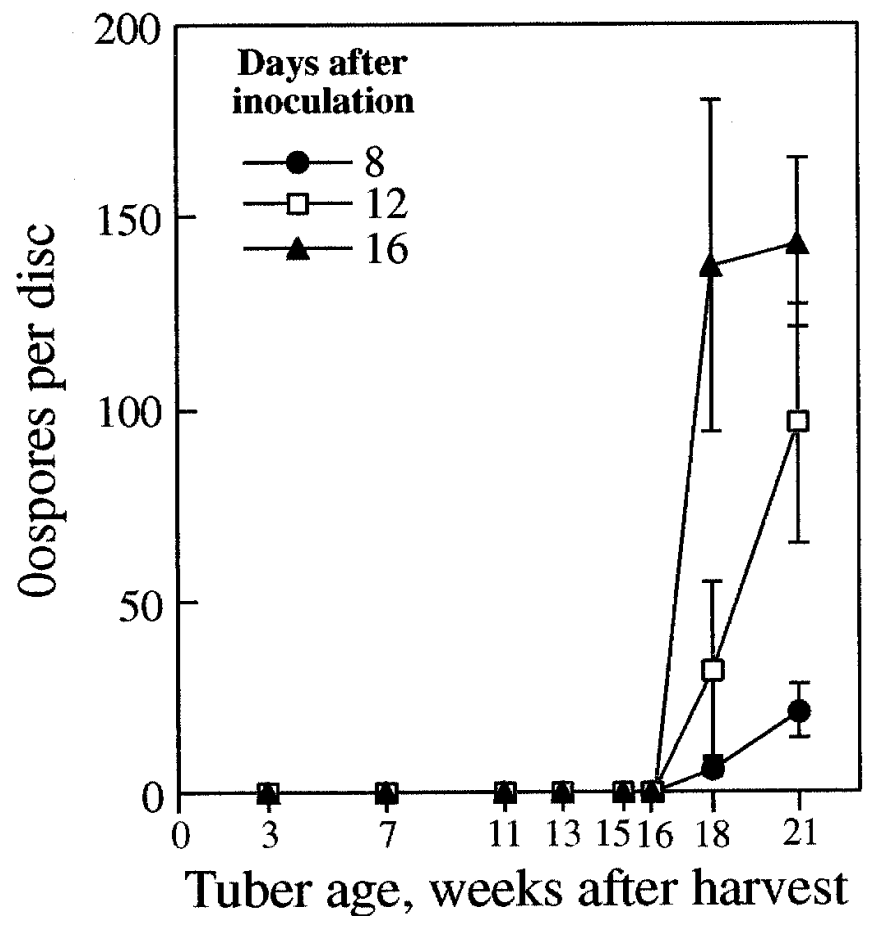

Fig. 1. Oospore formation of Phytophthora infestans in potato tuber discs (10-mm diameter) of $\mathrm{cv}$. Mondial stored at $4^{\circ} \mathrm{C}$ for various periods of time after harvest. Inoculation with isolates $314+317$. 


\section{RESULTS}

Oospore formation in tubers infected in the field. Out of the 90 blighted tubers (cv. Alpha) collected from the field in 1998 only two tubers had oospores. Both tubers were found in the plot coinoculated with isolates GE (A1) + EHF (A2) (Table 1). The numbers of oospores per tuber were 20 and 40. Out of the 90 infected tubers (cv. Mondial) collected in 2000 none formed oospores during the examination period of 12 weeks. To verify if both fungal mating types (TO497, A1; and 317, A2) colonized the tubers, sporangia were successfully collected from 63 tubers. They were inoculated onto leaf discs (cv. Mondial) together with either one of the tester isolates (314, A1; and 317, A2) and examined for oospore formation. Of these, 21 tubers were colonized by both mating types, 38 tubers with A1, and 4 tubers with A2. As previously described, no oospores were detected in the 21 tubers that were colonized by both mating types, indicating a possible suppression of oosporogenesis in the tubers.

Oospore formation in whole tubers under controlled conditions. In the first experiment, blight symptoms developed in all tubers after 1 week. After 2 to 16 weeks of incubation, no oospores were found (three tubers examined at biweekly intervals, total 24 tubers) in any tuber. The same inoculum produced $159 \pm$ 55 oospores per leaf disc (1-cm diameter) of potato cv. Mondial at $15^{\circ} \mathrm{C}$, indicating that tuber tissue is suppressive to oospore formation of Phytophthora infestans.

In the second experiment, 2 weeks after inoculation all tubers were blighted but no oospores were found. At 4 weeks a mean of 5,10 , and 25 oospores per tuber were detected in tubers of cvs. Nicola, Clauster, and Mondial, respectively, indicating that oospore formation was enhanced in old sprouting tuber relative to younger, dormant ones.

In the third experiment, 10 days after inoculation all tubers $(n=$ 3) showed blight symptoms except those incubated at $5^{\circ} \mathrm{C}$. Microscopical examinations made at 10 days and 5 weeks after inoculation revealed no oospores inside the tubers regardless of the temperature of inoculation $\left(11,17\right.$, or $\left.23^{\circ} \mathrm{C}\right)$ or the $\mathrm{A} 1+\mathrm{A} 2$ isolates used for coinoculation. At 5 weeks, slight blight was seen at $5^{\circ} \mathrm{C}$ with one tuber showing four oospores.

Oospore formation in tuber discs. Figure 1 presents data on oospore formation in tuber discs collected from potato tubers, cv. Mondial, at various times after harvest. No oospores were produced in tubers until aged in storage at $4^{\circ} \mathrm{C}$ for more than 16 weeks, whereas sporangial production in all discs was abundant (data not shown). At this time, small, white sprouts emerged from tuber buds, and tuber discs taken from such tubers enabled the fungus to produce oospores upon coinoculation with A1 + A2 sporangia (isolates $314+317$ ) (Fig. 1). This was also true in cvs. Clauster and Nicola inoculated with isolates $314+317$ (data not shown) and to a much lesser extent in cv. Alpha.

Tuber discs from dormant or sprouting tubers (stored for 5 and 25 weeks at $4^{\circ} \mathrm{C}$, respectively) of cv. Mondial were coinoculated with eight other pairs of $\mathrm{A} 1+\mathrm{A} 2$ isolates whose origin was from either potato or tomato. Leaf discs of this cultivar were similarly inoculated for comparison. Results (Table 2) show that after 10 days of incubation dormant tuber discs allowed for no oospore production, whereas sprouting tuber discs enabled an average of $19 \pm 20$ oospores to be produced in a disc. Leaf discs were significantly more supportive to oospore formation (198 \pm 53 oospores per disc) than tuber discs. No significant differences were found between the fungal pairs in their ability to form oospores in either tissue (data not shown).

Further experiments were done with cvs. Alpha and Bintje (Table 3). Oospore counts were taken 20 days after inoculation. Dormant tuber discs were generally suppressive, and sprouting tuber discs were supportive of oospore formation except with dormant cv. Bintje in which two pairs were able to produce oospores. US-1 + US-8 failed to produce oospores even on cv. Alpha leaf discs, but did produce oospores on sprouting cv. Bintje tuber discs. It thus appeared that of the five cultivars tested only cv. Bintje allowed for a few oospores to be formed in discs derived from dormant tubers. Similar failure of US1 + US8 to produce oospores in potato tubers was observed by Medina et al. (33).

Six pairs of $\mathrm{A} 1+\mathrm{A} 2$ isolates were tested in tuber discs taken from cv. Bintje tubers either dormant or sprouting. Unlike other experiments, sprouting took place in the greenhouse at $22^{\circ} \mathrm{C}$ for 4 or 10 weeks. Of the six fungal pairs used (Table 1) on 20 tuber discs of each tuber type only three discs (out of 360) showed one to six oospores (data not shown).

The data collected indicated that tuber discs of cv. Alpha were less supportive of oospore production compared to other cultivars even after prolonged storage at $4^{\circ} \mathrm{C}$ (9 months), which allowed strong sprouting. Therefore, such tubers were used to evaluate the efficacy of various environmental and chemical treatments on enhancing oospore production.

We observed that tuber discs (cv. Alpha) taken from the perimeter of the tuber ( 2 to $12 \mathrm{~mm}$ deep) or its medulla (30 to $40 \mathrm{~mm}$ deep) were similarly conducive to oospore formation, allowing for only 4 to 12 and 3 to 10 oospores, respectively, to be formed in a disc after coinoculation with either one of five $\mathrm{A} 1+\mathrm{A} 2$ isolate pairs.

When sprouting tubers were pretreated at $35^{\circ} \mathrm{C}$ (darkness) for $48 \mathrm{~h}$ a small, but significant, increase in oospore yield occurred (17 \pm 4 oospores per disc) compared with tubers maintained at $4^{\circ} \mathrm{C}(4.8 \pm 2$ oospores per disc $)$.

To examine whether internal conditions inside a tuber might be suppressive, we allowed 20 tuber discs of various cultivars (all sprouting) to produce oospores in a regular, or a Parafilm-sealed, petri dish. Data presented in Table 4 show that in sealed dishes oospore production was reduced by 88 to $100 \%$ relative to nonsealed dishes. When similar tuber discs were inoculated with either one of the fungal strains, sporangial yields in sealed plates were reduced by 64 to $79 \%$ relative to control nonsealed plates (data not shown). At reduced airflow, as might occur inside a potato tuber, both sexual and asexual sporulation were significantly inhibited.

The effect of sugars in tuber discs. Results presented in Figure 2 show that sucrose, fructose, and glucose enhanced oospore formation by isolates BI + KG. Maximal (approximately threefold) increments were obtained with $6.25 \mu \mathrm{mol}$ per disc of sucrose and $12.5 \mu \mathrm{mol}$ per disc of either glucose or fructose. A similar study was conducted with discs from dormant cv. Mondial tubers. Tuber discs treated with water yielded 0 oospores upon coinoculation with isolates $314+317$, whereas those treated prior

TABLE 2. Oospore formation by Phytophthora infestans in potato leaf discs and tuber discs inoculated with isolates of potato or tomato origin ${ }^{\mathrm{x}}$

\begin{tabular}{lccc}
\hline & & \multicolumn{2}{c}{ No./tuber disc ${ }^{\mathrm{z}}$} \\
\cline { 3 - 4 } A1 + A2 pairing & No./leaf disc & Sprouting tubers & Dormant tubers \\
\hline $314+317$ & $227 \mathrm{c}$ & $61 \mathrm{~b}$ & $0 \mathrm{a}$ \\
$314+\mathrm{US}-7$ & $291 \mathrm{~b}$ & $10 \mathrm{a}$ & $0 \mathrm{a}$ \\
$870+$ KG & $153 \mathrm{~b}$ & $11 \mathrm{a}$ & $0 \mathrm{a}$ \\
$870+$ TUR & $233 \mathrm{~b}$ & $3 \mathrm{a}$ & $0 \mathrm{a}$ \\
TO497 + KG & $167 \mathrm{~b}$ & $12 \mathrm{a}$ & $0 \mathrm{a}$ \\
TO497 + TUR & $199 \mathrm{~b}$ & $7 \mathrm{a}$ & $0 \mathrm{a}$ \\
TO497 + 317 & $159 \mathrm{c}$ & $44 \mathrm{~b}$ & $0 \mathrm{a}$ \\
TO497 + US-7 & $122 \mathrm{c}$ & $21 \mathrm{~b}$ & $0 \mathrm{a}$ \\
$96933+$ KG & $231 \mathrm{~b}$ & $3 \mathrm{a}$ & $0 \mathrm{a}$ \\
Mean & $198 \pm 53 \mathrm{~b}$ & $19 \pm 20 \mathrm{a}$ & $0 \mathrm{a}$ \\
\hline
\end{tabular}

${ }^{x}$ Oospores per disc $(n=10)$ counted at 10 days after inoculation. Values within column followed by different letters are significantly different at the $5 \%$ probability level (Duncan's multiple range test).

${ }^{y}$ Leaf discs (10-mm diameter) were removed from the middle leaves of 6-week-old potato plants of cv. Mondial grown in the greenhouse.

$\mathrm{z}$ Tuber discs (10-mm diameter, 3-mm thick) were removed from tubers kept at $4^{\circ} \mathrm{C}$ for 4 (dormant) or 25 (sprouting) weeks at $4^{\circ} \mathrm{C}$. 
to inoculation with $0.45 \%$ of either glucose, galactose, sucrose, lactose, sorbitol, or mannitol enabled the following respective mean number of oospores to be produced per disc: 15, 3, 6, 2, 12, and 7. Dormant tubers of cvs. Clauster, Nicola, and Alpha yielded 0 oospores per disc upon coinoculation with isolates $314+317$, whereas 1,11 , and 0 oospores per disc, respectively, were obtained in discs treated with $0.45 \%$ glucose.

The effect of amino acids in tuber discs. The effects of 19 amino acids (50 $\mu \mathrm{g}$ per disc, each) on sexual sporulation of Phytophthora infestans $(\mathrm{BI}+\mathrm{KG}, \mathrm{A} 1+\mathrm{A} 2$ pair) in potato tuber discs of cv. Alpha (25 weeks after harvest, sprouting) are given in Figure 3. Six amino acids significantly enhanced (approximately twofold) oospore formation, whereas six other amino acids had a small, though significant, suppression effect. Histidine and leucine prevented oospore formation but also reduced sporangial formation (data not shown). Valine and leucine were reported to inhibit oospore formation in vitro (13).

Casein (enzymatic hydrolysate) solutions were tested with tuber discs derived from dormant tubers of cvs. Mondial, Clauster, Nicola, and Alpha. Tuber discs were coinoculated with isolates $314+317$, and oospore counts were taken 10 days after. No oospores were formed in water-treated discs of either cultivar. Casein hydrolysate of either 2, 20, and $200 \mu \mathrm{g}$ per disc allowed the fungus to produce 6 to 13,2 to 3,1 to 6 , and 7 to 10 oospores per disc in cvs. Mondial, Clauster, Nicola, and Alpha, respectively. Mean numbers of oospores in casein-treated discs were significantly higher than in water-treated discs from each cultivar, but oospore counts in the various doses did not differ significantly. A similar effect of casein hydrolysate was observed when discs

TABLE 3. Oospore formation by Phytophthora infestans in tuber discs from dormant and sprouting tissues of potato cvs. Alpha and Bintje ${ }^{\mathrm{x}}$

\begin{tabular}{lrcccc}
\hline & & \multicolumn{4}{c}{ No./tuber disc $^{\mathrm{z}}$} \\
\cline { 4 - 6 } $\begin{array}{l}\text { A1 + A2 } \\
\text { pairing }\end{array}$ & $\begin{array}{c}\text { No./leaf } \\
\text { disc }\end{array}$ & $\begin{array}{c}\text { Dormant } \\
\text { Alpha }\end{array}$ & $\begin{array}{c}\text { Sprouting } \\
\text { Alpha }\end{array}$ & $\begin{array}{c}\text { Dormant } \\
\text { Bintje }\end{array}$ & $\begin{array}{c}\text { Sprouting } \\
\text { Bintje }\end{array}$ \\
\hline TO497 + 317 & $35 \mathrm{~b}$ & $0 \mathrm{a}$ & $0 \mathrm{a}$ & $0 \mathrm{a}$ & $4 \mathrm{a}$ \\
BI + KG & $178 \mathrm{~b}$ & $0 \mathrm{a}$ & $26 \mathrm{a}$ & $0 \mathrm{a}$ & $13 \mathrm{a}$ \\
US1 + US8 & $0 \mathrm{a}$ & $0 \mathrm{a}$ & $0 \mathrm{a}$ & $0 \mathrm{a}$ & $3 \mathrm{~b}$ \\
GR + YA & $94 \mathrm{c}$ & $0 \mathrm{a}$ & $1 \mathrm{a}$ & $6 \mathrm{a}$ & $28 \mathrm{~b}$ \\
BR-5 + YA & $126 \mathrm{~b}$ & $0 \mathrm{a}$ & $0 \mathrm{a}$ & $0 \mathrm{a}$ & $1 \mathrm{a}$ \\
HA + TUR & $100 \mathrm{~b}$ & $0 \mathrm{a}$ & $3 \mathrm{a}$ & $2 \mathrm{a}$ & $3 \mathrm{a}$ \\
Mean & $88.8 \mathrm{~b}$ & $0 \mathrm{a}$ & $5 \mathrm{a}$ & $1.3 \mathrm{a}$ & $8.7 \mathrm{a}$ \\
\hline
\end{tabular}

$x$ Values within columns followed by the same letter are not significantly different at the 5\% probability level (Duncan's multiple range test).

${ }^{y}$ Leaf discs (10-mm diameter) were removed from middle leaves of 6-weekold plants of potato cv. Alpha. Values represent mean number of oospores per disc at 10 days after inoculation $(n=10)$.

${ }^{z}$ Tuber discs (10-mm diameter, 3-mm thick) were removed from cv. Alpha stored at $4^{\circ} \mathrm{C}$ for 4 (dormant) or 40 (sprouting) weeks; Bintje stored at $4^{\circ} \mathrm{C}$ for 3 weeks (dormant) or first stored at $4^{\circ} \mathrm{C}$ for 40 weeks and then in the greenhouse for 1 week (green sprouting). Values represent mean number of oospores per disc at 20 days after inoculation $(n=20)$.

TABLE 4. Inhibitory effect of reduced airflow on oospore formation by Phytophthora infestans in potato tuber discs of various cultivars in petri dishes ${ }^{\mathrm{Z}}$

\begin{tabular}{llccc}
\hline $\begin{array}{l}\text { A1+ A2 } \\
\text { pairing }\end{array}$ & Cultivar & $\begin{array}{c}\text { Parafilm- } \\
\text { sealed dishes }\end{array}$ & $\begin{array}{c}\text { Nonsealed } \\
\text { dishes }\end{array}$ & \% Inhibition \\
\hline $96933+317$ & Mondial & $2 \mathrm{a}$ & $27 \mathrm{~b}$ & 93 \\
$96933+\mathrm{US}-7$ & Mondial & $1 \mathrm{a}$ & $27 \mathrm{~b}$ & 96 \\
$870+\mathrm{KG}$ & Mondial & $2 \mathrm{a}$ & $23 \mathrm{~b}$ & 100 \\
$870+317$ & Mondial & $2 \mathrm{a}$ & $9 \mathrm{~b}$ & 100 \\
$870+317$ & Clauster & $0 \mathrm{a}$ & $4 \mathrm{~b}$ & 100 \\
$870+317$ & Nicola & $1 \mathrm{a}$ & $8 \mathrm{~b}$ & 88 \\
Mean & & $1.3 \pm 0.8 \mathrm{a}$ & $16.3 \pm 10 \mathrm{~b}$ & \\
\hline
\end{tabular}

${ }^{\mathrm{z}}$ Oospores per disc; 20 tuber discs in a 9-cm petri dish, examined 12 days after inoculation. All sprouting tubers were stored for 25 weeks at $4^{\circ} \mathrm{C}$. Values in rows followed by different letters are significantly different at the $5 \%$ probability level ( $t$ test). were coinoculated with three other $\mathrm{A} 1+\mathrm{A} 2$ pairs of the fungus (data not shown).

The effect of plant hormones in tuber discs. Plant hormones that might affect plant senescence were tested for their effect on sexual reproduction of Phytophthora infestans in tuber discs. Abscisic acid (ABA), gibberellic acid (GA3), and methyljasmonate (MJ, vapor) were examined with isolates $314+317$ in discs derived from dormant tubers of cv. Mondial and chloroethylphosphonic acid (Ethephon) was tested with isolates BI + $\mathrm{KG}$ coinoculated onto discs derived from sprouting tubers of $\mathrm{cv}$. Alpha. Water-treated cv. Mondial discs and those treated with ABA of $1 \mu \mathrm{g}$ per disc showed no oospores. ABA at 2 and $4 \mu \mathrm{g}$ per disc enabled $1 \pm 2$ and $6 \pm 6$ oospores to be formed per disc, and GA3 at 1,2 , and $4 \mu \mathrm{g}$ per disc allowed production of $1 \pm 3,2 \pm 3$, and $7 \pm 7$ oospores per disc, respectively. MJ (10 $\mu \mathrm{l}$ applied onto a 7-cm-diameter filter paper in a 9-cm dish on which 10 discs were placed) had no effect. The effect of Ethephon in cv. Alpha is shown in Figure 4. Oospore formation was dependent on Ethephon concentration; at $3.1 \mu \mathrm{g}$ per disc an approximate threefold increase in oospore count was seen but counts were greatly reduced at 12.5 and $25 \mu \mathrm{g}$ per disc, with a total inhibition at $50 \mu \mathrm{g}$ per disc. A similar effect was obtained in discs inoculated with TO497 + 317 or TO497 + US-7 isolates (data not shown).

The effect of sterols in tubers discs. Cholesterol, $\beta$-sitosterol, and lanosterol of various doses were applied to tuber discs of cv. Alpha, and oospore formation, upon inoculation with $\mathrm{BI}+\mathrm{KG}$ $(\mathrm{A} 1+\mathrm{A} 2)$ isolates, was monitored 2 weeks later. Cholesterol and lanosterol at up to $100 \mu \mathrm{g}$ per disc did not affect oospore production in a significant manner (data not shown). $\beta$-Sitosterol increased oospore counts significantly at doses of 5 and $10 \mu \mathrm{g}$ per disc, but not at 2.5, 25, 50, or $100 \mu \mathrm{g}$ per disc (Fig. 5). Compared with a mean of $5 \pm 2$ oospores per disc in water controls, $11 \pm$ 3 oospores per disc were counted in discs treated with $\beta$-sitosterol at 5 and $10 \mu \mathrm{g}$ per disc. Also soybean-cooking oil affected oospore production. Soybean oil was dissolved in acetone and a 50- $\mu 1$ droplet per disc was applied to discs derived from dormant tubers of cv. Bintje. Twelve days after coinoculation with isolates TO497 + 317, oospore counts per disc were $0,0,8 \pm 12,13 \pm 23$,

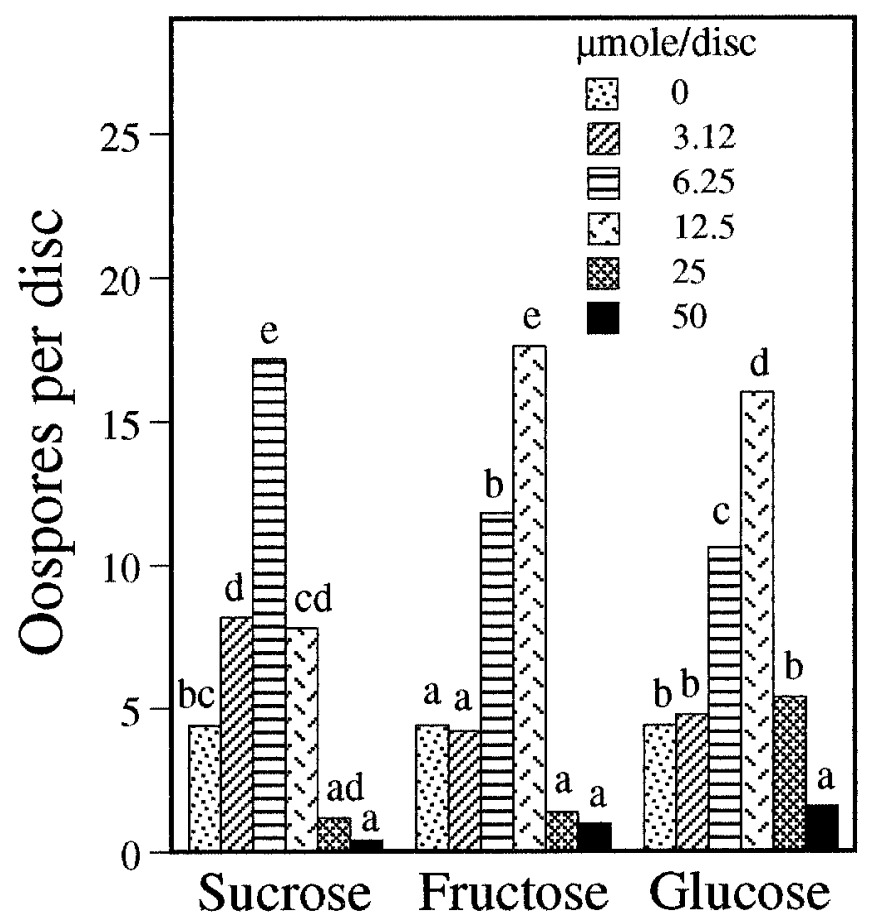

Fig. 2. The effect of sugars on oospore formation by Phytophthora infestans in potato tuber discs (10-mm diameter) of sprouting tubers (cv. Alpha) stored at $4^{\circ} \mathrm{C}$ for 25 weeks after harvest. Inoculation with isolates $\mathrm{BI}+\mathrm{KG}$. 
and $7 \pm 10$ for discs treated with water, acetone, and 125,250 , and $500 \mu \mathrm{g}$ of oil per disc, respectively. Lecithin of up to $200 \mu \mathrm{g}$ per disc had no effect.

\section{DISCUSSION}

Infected potato tubers serve as a major vehicle for the carryover of Phytophthora infestans from one season to the next (44). Not only can they initiate a new epidemic of late blight in a region or a country where they have been produced but also, by longdistance commercial transportation, in remote regions, countries, and even continents. Infected tubers will normally carry mycelia of the pathogen and when such tubers are planted in soil the fungus may produce sporangia through buds and lenticels, which may attack stems emerging from either the infected tuber or from neighboring tubers (39).

The displacement of the old population of Phytophthora infestans in Europe, and thereafter in the United States and Asia, in the 1980s of the late century $(12,17-19,22-24,29,31,42)$, is believed to have happened via potato tuber transportation from Mexico to Europe (36). This displacement introduced more aggressive genotypes of the fungus as well as the A2 mating type into the Western Hemisphere. Genetic recombination via oospores may have since increased aggressiveness $(15,20,37,45)$.

Oospores of Phytophthora infestans can survive extreme environments $(3,10,14)$. In some downy mildews, soilborne oospores and seedborne oospores initiated the disease in the field $(1,8)$. Although the role of oospores of Phytophthora infestans in the epidemiology of late blight has not yet been fully elucidated, it is reasonable to assume $(2,43)$ that their transportation in tubers would have a strong impact on population structure of the fungus when such tubers are planted.

It was imperative to quantitate the ability of A1 + A2 sporangia to reproduce sexually in tubers for at least two reasons: (i) to evaluate whether such infected tubers may serve as a source of recombinant oosporic inoculum, and (ii) to assess the risk of longdistance transportation of new recombinants of the fungus via such tubers.

In this study, oospores were only rarely observed in infected tubers from the field in Israel. Infected tubers collected from field plots inoculated with $\mathrm{A} 1+\mathrm{A} 2$ isolates showed oospores in 2 of 90 tubers. In another year none of 90 infected tubers showed oospores when examined periodically for 12 weeks in spite of the fact that 22 of them were colonized with both the A1 and A2 mating types. The paired isolates used in the field produced abundant oospores in detached leaflets of potato in petri dishes. These data indicate that tubers rarely support oospore production.

To elucidate the reasons for this low occurrence of oospores in infected tubers, artificial immersion inoculations of whole young tubers and wound inoculation of old tubers were done with sporangia of three pairs of $\mathrm{A} 1$ and $\mathrm{A} 2$ isolates of potato or tomato origin. Immersion inoculation produces infection in young tubers only (27). Results showed no oospore formation, thus reaffirming that some physical and physiological-biochemical factors of the tuber prevents the fungus from mating and making oospores.

One reason for the poor oospore production in tubers is their relatively low free water content. Previous data (7) show that oospore production in tomato and potato leaves floating on water in petri dishes is by far larger than similar leaves attached to plants that are enclosed in dew chambers (7) or in field-grown plants (6). The crucial role of free moisture was also demonstrated in the field (6). Potato crops exposed to heavy sprinkling irrigation produced more oospores in leaves upon coinoculation with A1 + A2 sporangia compared with crops subjected to light sprinkling irrigation. Oospore formation in tomato fruits, a much juicier tissue compared to tuber tissue, is also abundant (40; Y. Cohen, unpublished data). Another reason for differences in oospore production is aeration (34). Tuber tissue is much more compact compared to leaf tissue or tomato fruit tissue, and young dormant tuber tissue is more compact than old sprouting potato tuber

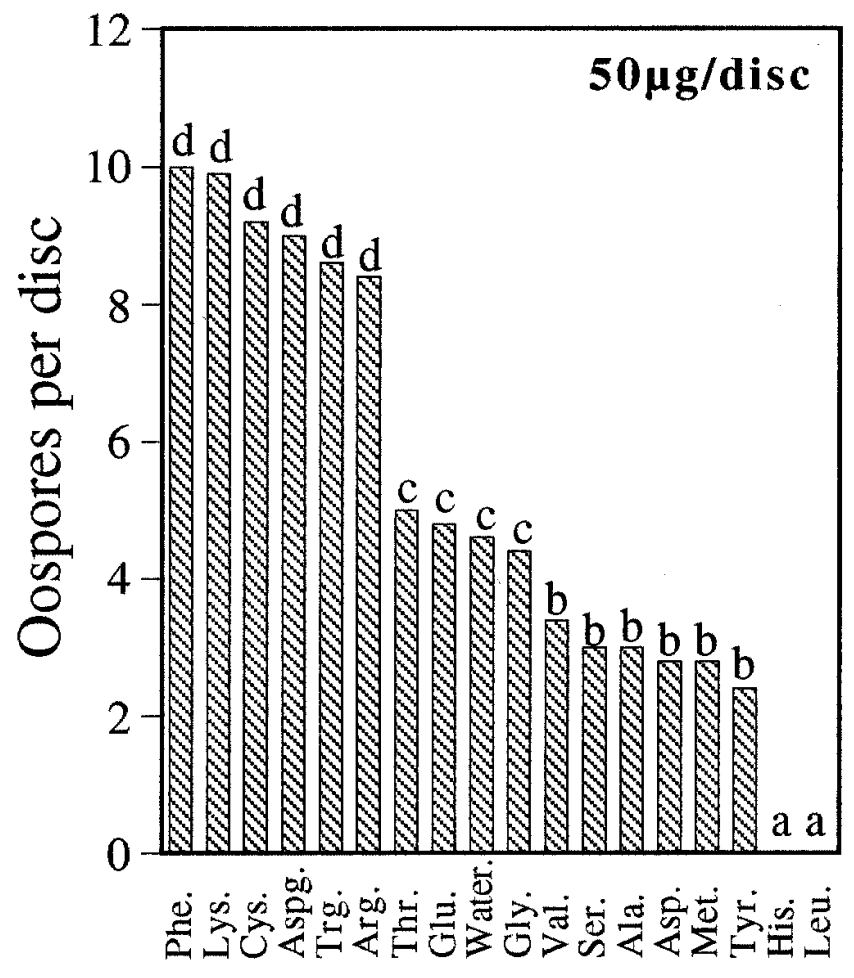

Fig. 3. The effect of amino acids on oospore formation by Phytophthora infestans in potato tuber discs (10-mm diameter) of sprouting tubers (cv. Alpha) stored at $4^{\circ} \mathrm{C}$ for 28 weeks after harvest. Inoculation with isolates $\mathrm{BI}+\mathrm{KG}$.

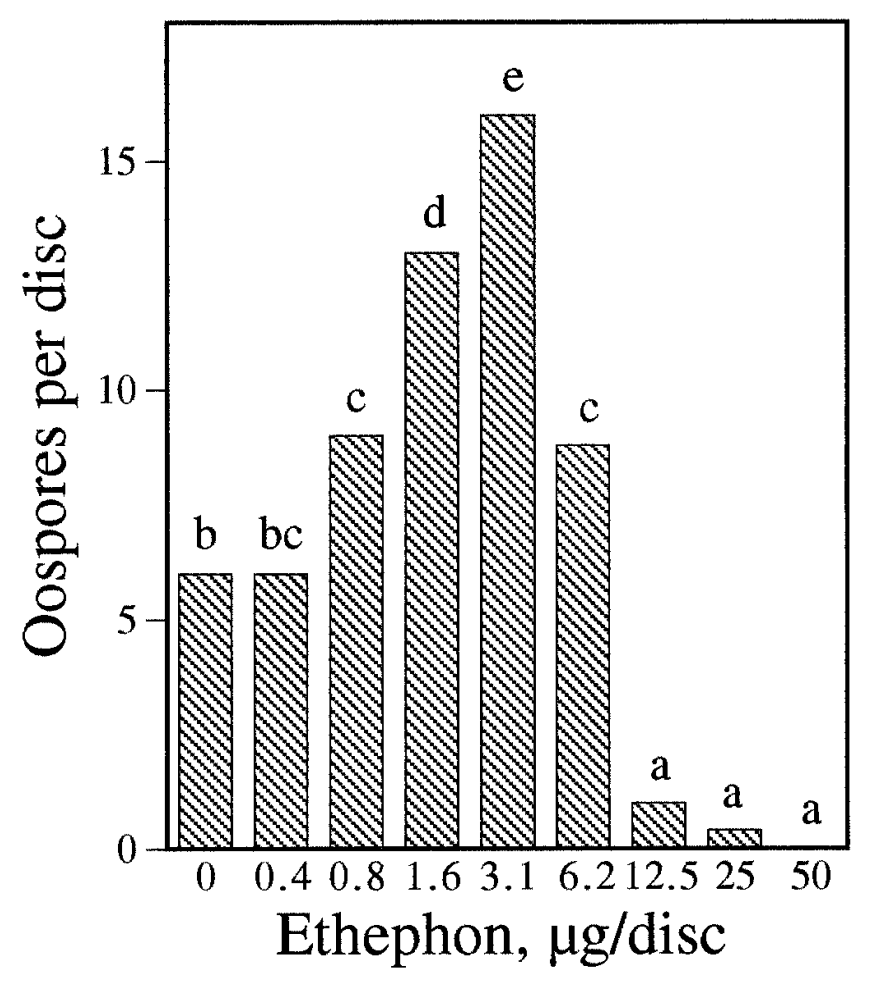

Fig. 4. The effect of Ethephon (chloroethylphosphonic acid) on oospore formation by Phytophthora infestans in potato tuber discs (10-mm diameter) of sprouting tubers (cv. Alpha) stored at $4^{\circ} \mathrm{C}$ for 30 weeks after harvest. Inoculation with isolates $\mathrm{BI}+\mathrm{KG}$. 
tissue. We found that approximately $20 \%$ more water could be infiltrated into old tuber discs compared with young tuber discs. Sealing experiments of tuber discs in petri dishes clearly indicated that reduced aeration suppresses sporangial production as well as oospore formation.

Another explanation for the difference between young and old tuber tissue in supporting oospore formation may be related to sugars and amino acids content. Aging increases free sugar and amino acid content (41). External application of sugars or amino acids (also peptides in the form of casein hydrolysate) had a positive effect on oospore formation relative to nontreated inoculated tuber discs. Ethephon, a compound degraded to ethylene in plants, enhanced oospore production in tuber discs, probably via the metabolic degradation of starch to sugars. External application of $\beta$-sitosterol also had a positive influence on oospore production (13).

Nevertheless, all externally applied compounds had a small, though significant, enhancing effect on oosporogenesis in tuber tissue. This implies that essential components are lacking from tubers to support either mating or formation of oospores, or alternatively, that inhibitory compounds are present. The fact that tuber tissue becomes more conducive with aging may result from either the formation of stimulators, the degradation of inhibitors, or both. More studies are required to understand the mechanisms controlling oospore formation in tuber tissues.

The fact that aged tubers are more supportive to oospore formation seems to have a little epidemiological significance. In the field, tubers lose sensitivity to late blight with aging (27). Artificial inoculation of tubers of various ages showed that at 48 days after planting $96 \%$ of them are sensitive, whereas at 95 days after planting only $\approx 50 \%$ are sensitive. In storage, sensitivity was further declined to $21 \%$ after 3 months (27). It seems, therefore, that when tubers are sensitive to infection they "refuse" oospore formation, whereas when they are resistant to infection they support oospore formation upon wound inoculation.

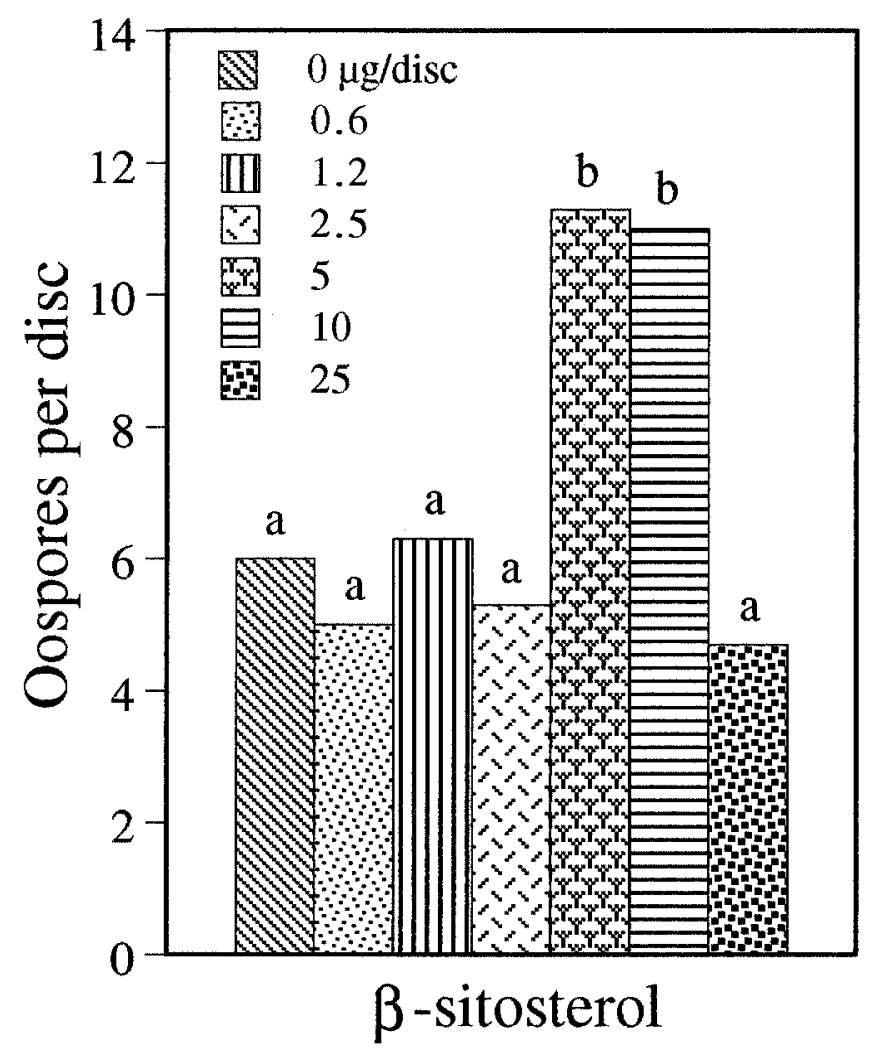

Fig. 5. Effect of $\beta$-sitosterol on oospore formation by Phytophthora infestans in potato tuber discs (10-mm diameter) of sprouting tubers (cv. Alpha) stored at $4{ }^{\circ} \mathrm{C}$ for 30 weeks after harvest. Inoculation with isolates $\mathrm{BI}+\mathrm{KG}$.
In conclusion, whole infected tubers harboring both mating types of Phytophthora infestans may rarely have oospores when harvested from the field. Upon storage of such tubers at 15 to $20^{\circ} \mathrm{C}$ no oospores are formed. Artificial inoculation of sprouting tubers, which rarely takes place in storage, may facilitate the production of oospores to an extent depending on the cultivar. Tubers seem to lack essential factors required for, or contain factors inhibitory to, oosporogenesis. The content of these factors changes during aging. Oospore formation in tuber tissue is by far lower than that of leaf tissue. Considering the generally low percentage of oospore germination $(3,4,14)$ and the low occurrence of oospores in potato tubers, it seems unlikely, although not impossible, that tubers serve as an important vehicle of oospores for either inoculum in situ or to remote locations.

\section{LITERATURE CITED}

1. Agrios, G. N. 1978. Plant Pathology. 2nd ed. Academic Press, New York.

2. Andersson, B., Sandstrom, M., and Stromberg, A. 1998. Indications of soil borne inoculum of Phytophthora infestans. Potato Res. 41:305-310.

3. Andrivon, D. 1995. Biology, ecology and epidemiology of the potato late blight pathogen Phytophthora infestans in soil. Phytopathology 85:1053-1056.

4. Chang, T. T., and Ko, W. H. 1991. Factors affecting germination of oospores of Phytophthora infestans. J. Phytopathol. 133:29-35.

5. Chang, T. T., and Ko, W. H. 1992. Inheritance of isozyme production and sexual reproduction in Phytophthora infestans. Can. J. Bot. 70: 379-383.

6. Cohen, Y., Farkash, S., Baider, A., and Shaw, D. S. 2000. Sprinkling irrigation enhances production of oospores of Phytophthora infestans in field-grown crops of potato. Phytopathology 90:1105-1111.

7. Cohen, Y., Farkash, S., Reshit, Z., and Baider, A. 1997. Oospore production of Phytophthora infestans in potato and tomato leaves. Phytopathology 87:191-196.

8. Cohen, Y., and Sackston, W. E. 1974. Seed infection and latent infection of sunflower by Plasmopara halstedii. Can. J. Bot. 52:231-238.

9. Deahl, K. L., DeMuth, S. P., Sinden, S. L., and Rivera-Pena, A. 1995. Identification of mating types and metalaxyl resistance in North American populations of Phytophthora infestans. Am. Potato J. 72:35-49.

10. Drenth, A., Janssen, E. M., and Govers, F. 1995. Formation and survival of oospores of Phytophthora infestans under natural conditions. Plant Pathol. 44:86-94.

11. Drenth, A., Tas, I. C. Q., and Govers, F. 1994. DNA fingerprinting uncovers a new sexually reproducing population of Phytophthora infestans in the Netherlands. Eur. J. Plant Pathol. 100:97-107.

12. Drenth, A., Turkensteen, L. J., and Govers, F. 1993. The occurrence of the A2 mating type of Phytophthora infestans in the Netherlands: Significance and consequences. Neth. J. Plant Pathol. 99:57-67.

13. Elliot, C. G. 1983. Physiology of sexual reproduction in Phytophthora. Pages 71-80 in: Phytophthora, its Biology, Taxonomy, Ecology and Pathology. D. C. Erwin, S. Bartnicki-Garcia, and P. H. Tsao, eds. The American Phytopathological Society, St. Paul, MN.

14. Fay, J. C., and Fry, W. E. 1997. Effects of hot and cold temperatures on the survival of oospores produced by United States strains of Phytophthora infestans. Am. Potato J. 74:315-323.

15. Flier, W. G., Turkensteen, L. J., and Mulder, A. 1998. Variation in tuber pathogenicity of Phytophthora infestans in the Netherlands. Potato Res. 41:345-354.

16. Frinking, H. D., Davidse, L. C., and Limburg, H. 1987. Oospore formation by Phytophthora infestans in host tissue after inoculation with isolates of opposite mating type found in Netherlands. Neth. J. Plant Pathol. 93:147-149.

17. Fry, W. E., and Goodwin, S. B. 1995. Recent migrations of Phytophthora infestans, Pages 89-95 in: Phytophthora infestans 150. L. J. Dowley, E. Bannon, L. R. Cooke, T. Keane, and E. O'Sullivan, eds. Boole Press, Dublin, Ireland.

18. Fry, W. E., and Goodwin, S. B. 1997. Re-emergence of potato and tomato late blight in the United States. Plant Dis. 81:1349-1357.

19. Fry, W. E., Goodwin, S. B., Dyer, A. T., Matuszak, J. M., Drenth, A., Tooley, P. W., Sujkowski, L. S., Koh, Y. J., Cohen, B. A., Spielman, L. J., Deahl, K. L., Inglis, D. A., and Sandlan, K. P. 1993. Historical and recent migrations of Phytophthora infestans: Chronology, pathways, and implications. Plant Dis. 77:653-661.

20. Gavino, P. D., Smart, C. D., Sandrock, R. W., Miller, J. S., Hamm, P. B., Lee, T. Y., Davis, R. M., and Fry, W. E. 2000. Implications of sexual reproduction for Phytophthora infestans in the United States: Generation of an aggressive lineage. Plant Dis. 84:731-735. 
21. Gisi, U., and Cohen, Y. 1996. Resistance to phenylamide fungicides: A case study with Phytophthora infestans involving mating type and race structure. Annu. Rev. Phytopathol. 34:549-572.

22. Goodwin, S. B. 1997. The population genetics of Phytophthora. Phytopathology 87:462-472.

23. Goodwin, S. B., Cohen, B. A., Deahl, K. L., and Fry, W. E. 1994. Migration from northern Mexico as the probable cause of recent genetic changes in populations of Phytophthora infestans in the United States and Canada. Phytopathology 84:553-558.

24. Goodwin, S. B., Cohen, B. A., and Fry, W. E. 1994. Panglobal distribution of a single clonal lineage of the Irish potato famine fungus. Proc. Natl. Acad. Sci. USA 91:11591-11595.

25. Goodwin, S. B., Sujkowski, L. S., and Fry, W. E. 1995. Rapid evolution of pathogenicity within clonal lineages of the potato late blight disease fungus. Phytopathology 85:669-676.

26. Grinberger, M., Kadish, D., and Cohen, Y. 1989. Occurrence of the A2 mating type and oospores of Phytophthora infestans in potato crops in Israel. Phytoparasitica 17:197-204.

27. Grinberger, M., Kadish, D., and Cohen, Y. 1995. Infectivity of metalaxyl-sensitive and -resistant isolates of Phytophthora infestans to whole potato tubers as affected by tuber aging and storage. Phytoparasitica 23:165-175.

28. Hanson, K., and Shattock, R. C. 1998. Formation of oospores of Phytophthora infestans in cultivars of potato with different levels of race-nonspecific resistance. Plant Pathol. 47:123-129.

29. Hohl, H. R., and Iselin, K. 1984. Strains of Phytophthora infestans with A2 mating type behaviour. Trans. Br. Mycol. Soc. 83:529-530.

30. Kadish, D., and Cohen, Y. 1988. Estimation of metalaxyl-resistance in Phytophthora infestans. Phytopathology 78:915-919.

31. Koh, Y. J., Goodwin, S. B., Dyer, A. T., Cohen, B. A., Ogoshi, A., Sato, N., and Fry, W. E. 1994. Migrations and displacements of Phytophthora infestans populations in east Asian countries. Phytopathology 84:922-927.

32. Medina, M. V., and Platt (Bud), H. W. 1999. Viability of oospores of Phytophthora infestans under field conditions in northeastern North America. Can. J. Plant Pathol. 21:137-143.

33. Medina, M. V., Platt (Bud), H. W., and Peters, R. D. 2000. Response of tubers of five potato cultivars to co-inoculation with US-1 and US-8 genotypes of Phytophthora infestans. Potato Res. 43:153-161.
34. M, D. J., and Zentmyer, G. A. 1971. Effects of oxygen and carbon dioxide tensions on sporangium and oospore formation by Phytophthora spp. Phytopathology 61:807-811.

35. Mosa, A. A., Kobayashi, K., Ogoshi, A., Kato, M., and Sato, N. 1991. Formation of oospores by Phytophthora infestans in inoculated potato tissues. Ann. Phytopathol. Soc. Jpn. 57:334-338.

36. Niederhauser, J. S. 1991. Phytophthora infestans: The Mexican connection. Pages 25-45 in: Phytophthora. J. A. Lucas, R. C. Shattock, D. S. Shaw, and L. R. Cooke, eds. British Mycological Society, Cambridge University Press, Cambridge.

37. Peters, R. D., Platt, H. W., Hall, R., and Medina, M. 1999. Variation in aggressiveness of Canadian isolates of Phytophthora infestans as indicated by their relative abilities to cause potato tuber rot. Plant Dis. 83: 652-661.

38. Pittis, J. E., and Shattock, R. C. 1994. Viability, germination and infection potential of oospores of Phytophthora infestans. Plant Pathol. 43: 387-396.

39. Rotem, J., and Shabbath, G. 1972. Transfer of Phytophthora infestans from blighted set tubers into the haulm of potato. Phytopathol. Mediterr. 11:109-112.

40. Smirnov, A. N., and Elansky, S. N. 1999. Oospore formation in the field population of Phytophthora infestans in Moscow region. (Russian with English summary) Mycol. Phytopathol. 33:421-429.

41. Sphycalla, J. P., and Desborough, S. L. 1990. Fatty-acids, membranepermeability, and sugars of stored potato-tubers. Plant Physiol. 94: 1207-1213.

42. Spielman, L. J., Drenth, A., Davidse, L. C., Sujkowski, L. S., Gu, W., Tooley, P. W., and Fry, W. E. 1991. A second world-wide migration and population displacement of Phytophthora infestans? Plant Pathol. 40: 422-430.

43. Strömberg, A., Persson, L., and Wikström, M. 1999. Infection of potato by oospores of Phytophthora infestans in soil. Plant Dis. 83:876.

44. Van der Zaag, D. E. 1956. Overwintering en epidemiologie van Phytophthora infestans, tevens enige nieuwe bestrijdingsmogelijkheden. Tijdschr. Plantenziekten 62:69-156.

45. Zwankhuizen, M. J., Govers, F., and Zadok, J. C. 1988. Development of potato late blight epidemics: Disease foci, disease gradients, and infection sources. Phytopathology 88:754-763. 